\title{
CAMBRIDGE لصRNALS
}

\section{Bulletin of the}

\section{AUSTRALIAN \\ MATHEMATIGAL SOGIETY}

Published for the Australian Mathematical Society

Editor: Graeme L. Cohen

Volume 87 • Issue 3 • June 2013

\section{CAMBRIDGE




\section{THE AUSTRALIAN MATHEMATICAL SOCIETY}

President: Peter J. Forrester

Secretary: P. J. Stacey

Treasurer: A. Howe

Editor of the Bulletin: Graeme L. Cohen
Department of Mathematics and Statistics

The University of Melbourne

Parkville Victoria 3010, Australia

Department of Mathematics and Statistics

La Trobe University

Bundoora Victoria 3086, Australia

Department of Mathematics

The Australian National University

Canberra ACT 0200, Australia

School of Mathematical Sciences

University of Technology, Sydney

Broadway, NSW 2007, Australia

\section{ASSOCIATE EDITORS}

\begin{tabular}{llll} 
R. S. Anderssen & G. Ivanov & M. Murray & B. Sims \\
J. Cossey & O. D. Jones & T. W. Ng & D. E. Taylor \\
B. D. Craven & G. I. Lehrer & I. Raeburn & H. B. Thompson \\
B. A. Davey & R. J. Loy & J. H. Rubinstein & D. Yost \\
A. Francis & K. L. McAvaney & J. Simpson & W. Zudilin \\
J. Grotowski & & & \\
\hline
\end{tabular}

Membership and correspondence: Applications for membership, notices of changes of address or title or position, members' subscriptions and correspondence related to accounts should be sent to the Treasurer. All other correspondence should be sent to the Secretary.

Subscriptions: The Bulletin of the Australian Mathematical Society began publication in 1969. Normally two volumes of three issues are published annually. Subscription prices for 2013 are $£ 311$ (\$572 in USA, Canada and Mexico) which includes print and electronic access. The electronic-only access price for 2013 is $£ 273$ (\$503 in USA, Canada and Mexico). Single parts cost $£ 57$ (\$105 in USA, Canada and Mexico). Prices include delivery by air where appropriate. EU subscribers who are not registered for VAT should add VAT at their country's rate. VAT registered subscribers should provide their VAT registration number.

Orders, which must be accompanied by payment, should be sent to a subscription agent, bookseller or direct to the publishers: Cambridge University Press, the Edinburgh Building, Shaftesbury Road, Cambridge CB2 8RU or, in the USA, Canada and Mexico, Cambridge University Press, Journals Fulfilment Department, 100 Brook Hill Drive, West Nyack, NY 10994-2133. Japanese prices are available from Kinokuniya Company Ltd, PO Box 55, Chitose, Tokyo 156, Japan. Periodicals postage is paid at New York, NY and additional mailing offices. POSTMASTER: send address changes in USA, Canada and Mexico to Bulletin of the Australian Mathematical Society, Cambridge University Press, Journals Fulfilment Department, 100 Brook Hill Drive, West Nyack, NY 10994-2133.

This journal is included in the Cambridge Journals Online service. Further information, and online access for subscribers, is available at http://journals.cambridge.org/baz.

Copying: This journal is registered with the Copyright Clearance Center (CCC), 222 Rosewood Drive, Danvers, MA 01923, USA. Organisations in the USA who are registered with the CCC may therefore copy material beyond the limits permitted by sections 107 and 108 of US copyright law subject to payment to $\mathrm{CCC}$ of the per-copy fee of $\$ 16.00$. This consent does not extend to multiple copying for promotional and commercial purposes. Code 0004-9727/2013 \$16.00.

Organisations authorised by the Copyright Licensing Agency may also copy material subject to the usual conditions. For all other use, permission should be sought from Cambridge or the American branch of Cambridge University Press.

Published by Cambridge University Press for the Australian Mathematical Publishing Association Incorporated. Printed in the United Kingdom at Bell \& Bain Ltd, Glasgow.

(C) 2013 Australian Mathematical Publishing Association Inc. 